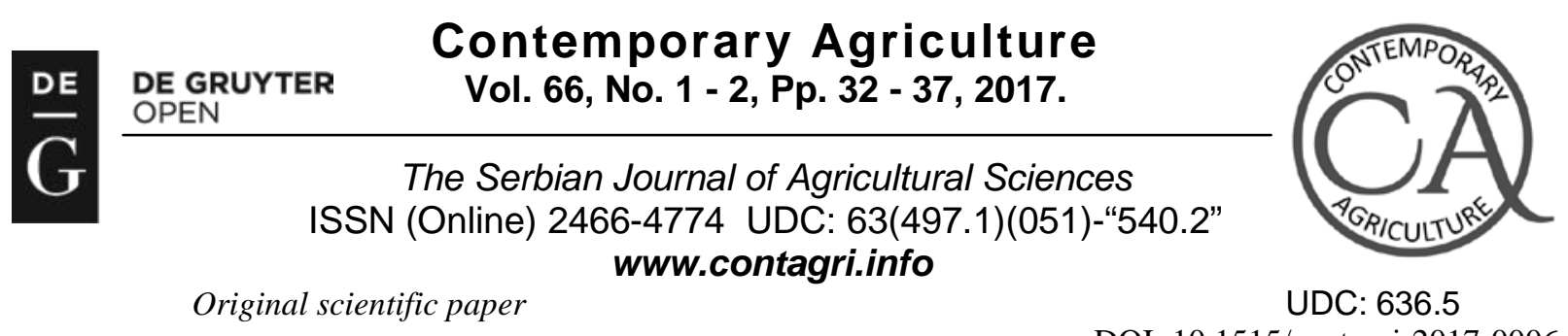

DOI: $10.1515 /$ contagri-2017-0006

\title{
THE EFFECT OF THERMAL CONDITIONING ON THYROID HORMONES, HATCHABILITY AND EMBRIONIC MORTALITY OF BROILERS DURING THE INCUBATION PERIOD*
}

\author{
Zoran RUŽIĆ ", Zdenko KANAČKI, Dragan ŽIKIĆ, \\ Gordana UŠĆEBRKA ${ }^{1}$
}

\begin{abstract}
Summary: The aim of this study was to examine the effect of thermal conditioning on the embryonic mortality, on the time of embryonic mortality, as well as to examine the effect of this temperature regime on hatching and on thyroid gland hormone levels. 400 fertile eggs, randomly divided into two groups with two repetitions, were used in this research. The control group was exposed to the standard temperature $\left(37.8^{\circ} \mathrm{C}\right)$ through the whole embryonic development. The second group was incubated under the standard conditions as the control group, up to $15^{\text {th }}$ day of embryonic development. During $16^{\text {th }}$, $17^{\text {th }}$ and $18^{\text {th }}$ day of embryonic development, the incubation temperature was increased to $39^{\circ} \mathrm{C}$ for 3 hours. From $19^{\text {th }}$ day up to the end of the incubation period the conditions of incubation were identical to those of the control group. Results of this study show that the applied treatment leads to an increase of concentration of free T3 hormone on the day 19 of embryonic development, as opposed to a decrease of free T4 hormone in the embryo's blood compared to the control group. The percentage of hatchability was $82.2 \%$ in the control group and $83.3 \%$ in the second group. The result shows that this way of thermal manipulation did not affect the embryonic mortality, which was $9.5 \%$ in the control group and $8.9 \%$ in the experimental group. It can be concluded that in this manner thermal conditioning may manifest the positive effect on the thyroid gland hormone levels without increasing embryonic mortality or disturbing the hatching percentage.
\end{abstract}

Key words: thermal conditioning, thyroid hormones, embryonic mortality, hatching

\section{INTRODUCTION}

The temperature of incubation is one of the most important physical factors which affect the embryo's development and hatching (Willemsen et al., 2010). Thermal conditioning represents cyclic change of incubation temperature on certain days of embryonic development, and noticed benefits at its use such as potentiality of thermotolerance and the effect on production performances of broilers. The positive effects of this treatment and its simple implication could easily lead to introducing this way of manipulation as a standard procedure in hatcheries. The mechanism of the effect of thermal conditioning shows that the temperature directly affects muscular tissue. It can also have an indirect effect by means of thermoregulatory axis, that is, through the endocrine system, particularly through the thyroid hormones (Kanački, 2010).

The first study that referred to the role of thyroid hormones in embryonic development with birds was set by Grossowicz (1946), when he noticed that if chicken embryos are injected anti-thyroid substance "thiourea" between the day 7 and the day 17, it leads to the delayed hatching even up to 10 days. It is known today that the hormones of thyroid gland affect the proper development of chickens' embryos by being involved in the muscular development control, lung development and represent the trigger for switching from the chorioallantoic to pulmonary respiration, enabling the retraction of the yolk sac, development of gastrointestinal tract and brain and affecting thermoregulation as well (McNabb and King, 1993; De Groef at al., 2013 McNabb and Darras, 2015; Yahav et al., 2004). The first

\footnotetext{
${ }^{1}$ Zoran Ružić, DVM, PhD student, Zdenko Kanački, DVM, MSc, PhD, Associate Professor, Dragan Žikić, PhD, Full Professor, Gordana Ušćebrka, PhD, Full Professor.

University of Novi Sad, Faculty of Agriculture, Trg Dositeja Obradovića 8, Novi Sad, Serbia

•Corresponding author: Zoran Ružić, e-mail: ruziczoran.1991@gmail.com

*This research is a part of the project supported by the Ministry of Education, Science, and Technological Development of Serbia (Project No. TR 31033)
} 
half of the incubation is distinctive in its limited capability of thyroid gland to produce T3 (triiodothyronine) and T4 (thyroxine) hormones (Thommes, 1987). It is only after 10.5 or 11.5 days of the embryonic development that the hypothalamic-pituitary-thyroid axis is activated and then the concentration of the thyroid hormones starts rising rapidly with slight fluctuations until the hatching out (Piestun et al., 2008; Yahav et al., 2004).

The level of the incubation temperature affects the time needed for the development of chicken embryo. It is known that temperatures above the optimal expedite the embryonic development and shorten the incubation time (Kaplan et al.1978), whereas lower temperatures decelerate this process and lead to the reverse effect (Black and Burggen, 2004). Additionally, if the incubation temperature is too high or too low, embryonic mortality will increase and hatchability can drastically decrease (De Souza Morita et al., 2010; Decuypere et al., 1979; Suarez et al., 1996). In their study, Kanački et al. (2013) concluded that thermal conditioning between the day 16 and day 18 of embryonic life gave positive effects such as the increase of chickens' weight in postnatal life, without influencing the mortality and conversion of food. They increased the incubation temperature above the optimal temperature $\left(37.9^{\circ} \mathrm{C}\right)$ for $1.5^{\circ} \mathrm{C}$ in duration of 3 hours a day. The same authors, in their previous study (Kanački at al., 2011) came to the conclusion that this way of thermal conditioning during the embryonic life leads to the increase of the total percentage of proteins and dry matter in meat after the day 42 of fattening. Stojanović et al. (2015) stated that the changes in body weight and meat quality were the result of increased proliferation of satellite cells, as well as increased growth and development of skeletal musculature during postnatal life. The question is: how can this kind of thermal manipulation affect the embryonic mortality and hatching of broilers since these parameters were not determined in the above mentioned studies?

The aim of this study is to examine the effect of thermal conditioning (increase of the incubation temperature to $39^{\circ} \mathrm{C}$ for three hours between the day 16 and 18 of embryonic development) on the mortality during the incubation and the time of embryonic mortality, as well as to examine the effect of this temperature regime on hatching. Also, the aim of this study was to determine the effect on thyroid gland hormone levels applying this way of thermal conditioning during the incubation period.

\section{MATERIALS AND METHODS}

400 fertile eggs of heavy hybrid "Ross 308” were used in this research derived from the parents' flock aged 54 weeks. 100 egg capacity incubators were used. The temperature in the incubators was regulated with the electric thermostat “Termoregulator ET-01" made by "Pro-Elektro", Novi Sad, Serbia. Humidity was kept between 50\% and $60 \%$ until the day 18 of embryonic development, and $75 \%$ from the day 19 until the end of the incubation. The ventilation was adjusted to the appropriate stage of the embryonic development.

The eggs were randomly divided into two groups with two repetitions. Thermal manipulation was conducted in the same way as it was in the study of Stojanović et al. (2011). The control (C) group (two incubators with 100 eggs each) were exposed to the standard incubation temperature of $37.8^{\circ} \mathrm{C}$ during the whole embryonic development. The second, thermally conditioned (TC) group (two incubators with 100 eggs each) was incubated under the standard conditions as the control group until $15^{\text {th }}$ day of embryonic development. During $16^{\text {th }}, 17^{\text {th }}$, and $18^{\text {th }}$ day of embryonic development the incubation temperature was increased to $39^{\circ} \mathrm{C}$ for 3 hours (from 9:00 to 12:00). From the day 19 until the end of the incubation the incubation conditions were identical to those in the control group.

Using the random sample method, 10 eggs were taken from both groups (5 eggs from each incubator) on $15^{\text {th }}$ day of the incubation and the same amount of eggs on $19^{\text {th }}$ day of the incubation in order to take samples of blood to determine the level of free T3 (fT3) and free T4 (fT4) hormones. The blood was taken using cardiac puncture method and was placed in heparinised tube and then went through a centrifuge process (15 minutes at 3000 spins per minute). Tests used to determine the level of free T3 and free T4 hormone were "EIAgen Free T3 Kit" and "EIAgen Free T4 Kit” (Adaltis S.r.I., Italy), which are tests based on the principle of competitive enzyme immunological method.

After hatching, all the remaining eggs were cracked open to determine fertility and the time when the embryonic mortality started. The beginning of the embryonic mortality was determined based on the appearance of the embryos and then they were compared to the phase in embryonic development according to Bellaris and Osmond (1998). Embryonic mortality and hatching were calculated upon the total of 360 eggs, i.e. 180 eggs per group, because previously, during the incubation, 20 eggs had been taken from both groups to determine the concentration of fT3 and fT4 hormones. Hatching, embryonic mortality and unfertilized eggs are expressed in percentages.

The results for the level of fT3 and fT4 hormones are shown as average values with standard deviation. The analysis of variance was conducted using the $\mathrm{F}$ test, whereas the comparison of groups' averages was conducted using the Student t-test on the level of importance of 95\% $(\mathrm{P}<0.05)$. Statistica 13 was used for the calculations. 


\section{THE RESULTS}

Vital embryos were found in all selected eggs. The effect of thermal conditioning on fT3 and fT4 hormones is summarised in Table 1 . The day before the use of thermal conditioning (day 15), there was no statistically significant difference between the control group and the experimental group for the levels of fT3 and fT4. On the other hand, on the day after the usage of thermal conditioning (day 19 of the embryonic development) there was a statistically significant difference on the level of $\mathrm{P}<0.05$ for the hormones of the thyroid gland when $\mathrm{C}$ and $\mathrm{TC}$ groups are compared. On the day 19 of the embryonic development, the average value of fT3 hormone level was higher in TC group compared to C group, while the average value for fT4 was higher in the control group.

Table 1: The effect of thermal conditioning on thyroid hormones

\begin{tabular}{|c|c|c|c|c|}
\hline \multirow{2}{*}{$\begin{array}{c}\text { The day of } \\
\text { embryonic } \\
\text { development }\end{array}$} & \multicolumn{2}{|c|}{ C } & \multicolumn{2}{|c|}{ TC } \\
\cline { 2 - 5 } & $\mathrm{fT}(\mathrm{pg} / \mathrm{ml})$ & $\mathrm{fT} 4(\mathrm{ng} / \mathrm{dl})$ & $\mathrm{fT} 3(\mathrm{pg} / \mathrm{ml})$ & $\mathrm{fT} 4(\mathrm{ng} / \mathrm{dl})$ \\
\hline day 15 & $1.65 \pm 0.179$ & $8.51 \pm 0.771$ & $1.61 \pm 0.139$ & $8.60 \pm 0.967$ \\
\hline day19 & $1.83 \pm 0.127^{*}$ & $11.81 \pm 0.969^{\#}$ & $1.95 \pm 0.111^{*}$ & $11.72 \pm 0.892^{\#}$ \\
\hline
\end{tabular}

The differences between the same symbols are on the level of significance of $\mathrm{P}<0.05$

Table 2 shows the hatching rate, unfertilized eggs and the percentage of embryonic mortality, which happened during the whole incubation period. These values were calculated upon the whole number of 180 eggs per group because 20 eggs had been taken out of the incubator during the incubation period to determine hormones fT3 and fT4.

Table 2: The effect of thermal conditioning on certain zoo-technical parameters

\begin{tabular}{|c|c|c|c|c|}
\hline Experimental group & Total number of eggs & Hatching (\%) & Unfertilized eggs (\%) & $\begin{array}{c}\text { Embryonic } \\
\text { mortality (\%) }\end{array}$ \\
\hline C & 180 & 82.2 & 8.3 & 9.5 \\
\hline TC & 180 & 83.3 & 7.8 & 8.9 \\
\hline
\end{tabular}

Table 3 depicts the total embryonic mortality for both examined groups, and the percentage of death in the specific period of the embryonic development. The highest percentage of the mortality for both the control and the experimental group is noticed within the first 15 days of the incubation period.

Table 3: The total account of embryonic mortality by groups during the incubation period and the period of its inception according to the embryonic period

\begin{tabular}{|c|c|c|c|c|}
\hline Experimental group & $\begin{array}{c}\text { The total } \\
\text { embryonic } \\
\text { mortality }\end{array}$ & $\begin{array}{c}\text { Mortality rate by 16 } \\
\text { day of incubation (\%) }\end{array}$ & $\begin{array}{c}\text { Mortality rate from } \\
\mathbf{1 6}^{\text {th }} \mathbf{t o ~ 1 9}^{\text {th }} \text { day of the } \\
\text { incubation (\%) }\end{array}$ & $\begin{array}{c}\text { Mortality rate from } \\
\mathbf{1 9}^{\text {th }} \text { day until the end } \\
\text { of the incubation (\%) }\end{array}$ \\
\hline C & $17(100 \%)$ & 58.8 & 23.5 & 17.7 \\
\hline TC & $16(100 \%)$ & 56.3 & 31.2 & 12.5 \\
\hline
\end{tabular}

\section{DISCUSSION}

There are two stages in the development of a chicken embryo during the incubation period: 1. Differentiation and 2. Growth (Deeming, 2005). The differentiation stage and organ formation is characteristic for the first half of the embryonic development (from day 1 to day 10.5). In this stage chicken embryos are capable of absorbing the heat from the surrounding air, because their temperature is on the lower level compared to the incubation temperature. Accelerated growth occurs in the second half of the embryonic development and the embryo has to free itself from the heat because the production of heat and the metabolism degree increase (Smith et al., 2008; Aminoraya et al., 2016). Due to the inability of the embryo to regulate its own temperature, the temperature is regarded as the fundamental factor of incubation (Givisiez at al., 2001).

Previous works (Yahav ae al., 2004; Aminoroaya at al., 2016; De Souza Morita et al., 2016) suggest that thermal conditioning, which implies cyclic changes in the temperature on particular days of embryonic development, leads to certain benefits. From the results obtained in our study it can be noticed that the values of both hormones are higher 
on the day 19 of the embryonic development compared to the day 15 . They are in agreement with the results of Lu et al. (2007) who determined that the level of T3 is significantly low for the great part of the embryonic development and it is rising only from the day 18, and peaks on the day 20 of the embryonic development, which coincides with the embryo's transition to pulmonary respiration. This is an extremely critical period for the survival since at this stage embryos need oxygen and energy for hatching. Until $15^{\text {th }}$ embryonic day, the level of $\mathrm{T} 4$ is basically constant, after which its concentration starts rising and peaks on $19^{\text {th }}$ embryonic day. The same study proved the positive correlation of the embryos' weight with T3 and T4 hormones, which could suggest that thyroid hormones have a very important role in normal growth and development during embryogenesis. The increased activity of the thyroid gland in the last week of embryonic development is predominantly stimulated by increased hypothalamic stimulation on TSH (thyroid-stimulating hormone), which is synthesised in the pituitary gland (De Groef et al., 2008).

Our study shows that the applied thermal manipulation leads to the increased concentration of fT3 hormone on $19^{\text {th }}$ embryonic day and, contrary to this, it causes decrease of fT4 concentration in embryos' blood compared to the control group on the same day (Table 1). These results are in agreement with the results of Kanački et al. (2013). Increased concentration of thyroid hormones, especially fT3, has a very important role in broilers' growth and development and can be considered as one of the essential factors in potency of thermoregulation (Piestun et al, 2008) and creation of better slaughtering features (Kanački et al., 2013). Aminoroaya et al. (2016) examined the influence of similar thermal manipulatiom and they took out blood for the analysis after hatching. According to their study, T3 values in the treated group were higher compared to the control group, which is in agreement with our results. Right after the hatching, T4 values were also higher in the treated group compared to the control group, which is not in agreement with the results we obtained. One of the possible reasons for this disparity could be the fact that our group contained more male units, which around $18^{\text {th }}$ day of embryonic development have slightly lower T4 values compared to female units (Lu et al., 2007). This cannot be determined with certainty since sexing of broilers' embryos was not performed in our study. The second possible reason for lower fT4 level with thermal conditioned embryos compared to the control group could lie in the concentration of fT3, which is slightly increased. According to Visser (1996), T4 represents precursor for T3 synthesis which is biologically active, thus the increase in fT3 can lead to decrease in fT4, owing to increased process of monodeiodination which is under the influence of growth hormone (Kanački et al., 2013).

The hatching percentage (Table 2) did not differ from the control group (82.2\%) and thermally conditioned group (83.3\%) on a large scale. Other authors (Yahav et al., 2004; Aminoroaya et al., 2016), also came to the same conclusion that this kind of thermal manipulation does not affect the percentage of hatching. Contrary to our results, Collin et al. (2007), who used thermal conditioning between $16^{\text {th }}, 17^{\text {th }}$ and $18^{\text {th }}$ day of embryonic development for 3 hours a day with the temperature of $39.5^{\circ} \mathrm{C}$, came to the conclusion that this kind of manipulation improves the hatching out percentage with the statistic significance of $95 \%$ compared to the control group, but that this thermal manipulation does not have a negative effect on the broilers' growth in postembryonic development.

The total embryonic mortality (Table 3) did not differ considerably in the control and the treated group. The highest percentage of embryonic mortality occurs in the first 15 days of the incubation, which of course is not connected to thermal manipulation applied from $16^{\text {th }}$ day of embryonic development. During the period of thermal conditioning (from $16^{\text {th }}$ to $19^{\text {th }}$ day) there was a slight increase in embryonic mortality within TC (31.2\%), whereas in the control group this percentage was lower (23.5\%) for the same period. On the other hand, after the usage of thermal conditioning a reverse process occurs, i.e. the embryonic mortality becomes slightly higher in the control group (17.6\%) compared to the treated group (12.5\%), which leads to the conclusion that the total embryonic mortality in this study does not change related to the applied thermal manipulation regime. De Souza Morita et al. (2010) underline that the embryos are more sensitive to higher temperatures at the end of the incubation period because higher incubation temperature for a longer period of time leads to intensive loss of water in the eggs, which causes late mortality due to dehydration of embryos. In this study, they used constant incubation temperature of $39^{\circ} \mathrm{C}$ from the beginning until the end of the embryonic development, which was the cause of the increased embryonic mortality. At the same time, in the study of Williamsen et al. (2010), the thermal manipulation was applied on the same days as it was in our experiment, but the temperature was raised to $40.6^{\circ} \mathrm{C}$ for 24 hours constantly. Our study did not use such an intensive thermal manipulation during the whole incubation period, nor did it use extremely high temperatures that could have caused the embryonic mortality, thus there was no increase in the total of the embryonic mortality. These observations lead us to the conclusion that the thermal conditioning needs to be limited within narrow boundaries so that the positive effects could be displayed, and also that these temperatures do not cause the embryonic mortality. 


\section{CONCLUSION}

Based on the presented facts, it can be concluded that the thermal conditioning applied in the study characterized by increasing the incubation temperature above the optimal $\left(37.8^{\circ} \mathrm{C}\right)$ to $39^{\circ} \mathrm{C}$ for 3 hours a day on $16^{\text {th }}, 17^{\text {th }}$ and $18^{\text {th }}$ day of the embryonic development causes a slight increase in fT3 level on $19^{\text {th }}$ embryonic day as well as a slight decrease of fT4 concentration on the same day of the embryonic development. This type of thermal manipulation during the broilers' incubation did not leave any negative effect on the percentage of hatching. Furthermore, it did not affect the total embryonic mortality.

\section{REFERENCES}

AMINOROAYA K, SADEGHI AA, ANSARI-PIRSARAEI Z, KASHAN N: The Effects of Cyclical Higher Incubation Temperatures on Body and Organs Weights, Thyroid Hormones and HSP70 Gene Expression of Newly Hatched Broiler Chicks. Kafkas Univ Vet Fak Derg 22(4)613-8, 2016.

BELLAIRS R, OSMOND M: The atlas of chick development. Academic Press. London. 2nd edition. pp. 411-44, 1998. BLACK JL, BURGGREN WW: Acclimation to hypothermic incubation in developing chicken embryos (Gallus domesticus):I. Developmental effects and chronic and acute metabolic adjustments. J. Exp. Biol. 207(9)1543-52, 2004.

COLLIN A, BERRI C, TESSERAUD S, RODON R, SKIBA-CASSY S, et al: Effects of Thermal Manipulation During Early and Late Embryogenesis on Thermotolerance and Breast Muscle Characteristics in Broiler Chickens. Poultry Science 86,795-800, 2007.

DE GROEF B, GROMMEN VHS, DARRAS MV: Hatching the cleidoic egg: the role of thyroid hormones. Frontiers in Endocrinology. Experimental Endocrinology, Vol.4(63), 2013.

DE SOUZA MV, BOLELI IC, DE OLIVEIRA JA: Hematological and Incubation Parameters of Chicks from Young Breeders Eggs: Variation with Sex and Incubation Temperature. Int.J.Poult.Sci., 9(6):606-12, 2010.

DE GROEF B, GROMMEN SVH, DARRAS VM: The chicken embryo as a model for developmental endocrinology: development of the thyrotropic, corticotropic and somatotropic axes. Mol.Cell.Endocrinol. 293, 17-24, 2008.

DECUYPERE E, NOUWEN EJ, KUHN ER, GEERS R, MICHELS H: Differences in serum iodohormone concentration between chick embryos with and without the bill in the air chamber at different incubation. Gen. Comp. Endocrinol. 37, 264-7, 1979.

Deeming, D.C.: Yolk sac, body dimensions, and hatchling quality of ducklings, chicks, and poults. Br Poultry Sci, 46, 560-4, 2005.

GIVISIEZ PEN, DA SILVA MM, MAZZI CM, FERRO MIT, FERRO JA, GONZALES E, MACARI M: Heat or cold chronic stress affects organ weights and HSP70 levels in chicken embryos. Can J Anim Sci, 81, 83-7, 2001.

GROSSOWICZ N: Influenceof thiourea on development of the chick embryo. Exp.Biol.Med. 63, 151-2, 1946.

KANAČKI Z, STOJANOVIĆ S, UŠĆEBRKA G, ŽIKIĆ D: The effect of modification of incubation factors on the quality of broiler chickens meat. $3^{\text {rd }}$ International Congress: “New perspectives and challenges of sustainable livestock production”, October 5-7, Belgrade, Biotechnology in Animal Husbandry, 27 (4): 1605-11, 2011.

KANAČKI Z, UŠĆEBRKA G, STOJANOVIĆ S, ŽIKIĆ D: Modified incubation factors and thyroid hormones as a mediators of chicken muscle quality. XV European Symposium on the Quality of Eggs and Egg Products. XXI European Symposium on the Quality of Poultry Meat. Bergamo, Italy 15 -19. 09. 2013. Vol.69

KANAČKI Z: Uticaj promena faktora inkubacije na endokrini sistem i faktore rasta teških hibrida pilića. PhD Thesis, Faculty of Agriculture, University of Novi Sad, Serbia, 2010.

KAPLAN S, KOLESARI GL, BAHR JP: Temperature dynamics of the fertile chicken egg. Am. J. Physiol. 234, 183-7, 1978.

LU JW, MCMURTRY JP, COON CN: Developmental Changes of Plasma Insulin, Glucagon, Insulin-like Growth Factors, Thyroid Hormones, and Glucose Concentrations in Chick Embryos and Hatched Chicks. Poultry Science 86, 673-83, 2007.

MCNABB FMA, KING DB: Thyroid hormones effects on growth development and metabolism. In: Schreibman, M.P., Scanes, C.G., PANG, P.K.T. (Eds.),The Endocrinology of Growth Development and Metabolism in Vertebrates. Academic Press, New York, pp.393-417,1993.

MCNABB FMA, DARAS VM: Thyroids. In: Sturkie’s Avian Physiology (Scanes C. ed).. Academic Press and Elsevier, New York, pp. 535-547, 2015.

PIESTUN Y, SHINDER D, RUZAL M, HALEVY O, YAHAV S: The effect of thermal manipulations during the development of the thyroid and adrenal axes on in-hatch and post-hatch thermoregulation. Journal of Thermal Biology, 33, 413-8, 2008.

SMITH LD, BRUGGEMAN V, DEBONNE M, TONA JK, KAMERS B, EVERAERT N, WITTERS A, ONAGBESAN O, ARCKENS L, DE BAERDEMAEKER J, DECUYPERE E: The effect of nonventilation during early incubation on the embryonic development of chicks of two commercial broiler strains differing in ascites susceptibility. Poultry Sci, 87, 551-60, 2008.

STOJANOVIĆ S, KANAČKI Z, UŠĆEBRKA G, ŽIKIĆ D: Influence of modified incubation factors on carcass characteristics of broiler chickens. Biotechnology in Animal Husbandry. 27(4): 1621-7, 2011.

STOJANOVIĆ S, ŽIKIĆ D, KANAČKI Z, UŠĆEBRKA G: Characteristics of embryonic and postnatal development of the skeletal muscles of broilers caused by temperature manipulation during the incubation. International symposioum on animal science 2015. Novi Sad, Serbia, 09-11.09.2015. pp. 68 
SUAREZ ME, WILSON HR, MCPHERSON BN, MATHER FB, WILCOX CJ: Low temperature effects on embryonic development and hatch time. Poult. Sci. 75,924-32, 1996.

THOMMES RC: Ontogenesis of thyroid function and regulation in the developing chick embryo. J. Exp. Zool., 1,273-9, 1987.

VISSER TJ: Pathways of thyroid hormone metabolism. Acta Medica Austriaca, 23(1-2)10-16, 1996

WILLEMSEN H, KAMERS B, DAHLKE F, HAN H, SONG Z, ANSARI PIRSARAEI Z, TONA K, DECUYPERE E, EVERAERT N: High- and low-temperature manipulation during late incubation: Effects on embryonic development, the hatching process, and metabolism in broilers. Poultry Science, 89, 2678-90, 2010.

YAHAV S, SASSON RATH R, SHINDER D: The effect of thermal manipulations during embryogenesis of broiler chicks (Gallus domesticus) on hatchability, body weight and thermoregulation after hatch. Journal of Thermal Biology, 29,245-50, 2004.

\title{
UTICAJ TERMALNOG KONDICIONIRANJA NA HORMONE ŠTITASTE ŽLEZDE, LEŽENOST I EMBRIONALNI MORTALITET TOVNIH PILIĆA U TOKU INKUBACIJE
}

\author{
Zoran RUŽIĆ, Zdenko KANAČKI, Dragan ŽIKIĆ, \\ Gordana UŠĆEBRKA
}

Izvod: Cilj ovog rada je da se ispita uticaj termalnog kondicioniranja na embrionalni mortalitet, da se odredi vreme nastanka embrionalnog mortaliteta kao i da se ispita uticaj ovog temperaturnog režima na leženost i na nivoe hormona štitaste žlezde. U ovom istraživanju korišćeno je 400 oplođenih jaja koja su nasumice podeljena u dve grupe sa po dva ponavljanja. Kontrolna grupa bila je podvrgnuta standardnoj temperaturi inkubacije $\left(37,8^{\circ} \mathrm{C}\right) \mathrm{u}$ trajanju celog embrionalnog razvoja. Druga grupa je inkubirana pod standardnim uslovima kao i kontrolna grupa do 15. dana embrionalnog razvoja. U toku 16., 17. i 18. dana embrionalnog razvoja temperatura inkubiranja je bila povećana na $39^{\circ} \mathrm{C} \mathrm{u}$ trajanju od $3 \mathrm{~h}$. Od 19 . dana do kraja inkubacije uslovi inkubiranja su bili identični kao u kontrolnoj grupi. Rezultati ove studije ukazuju da primenjivani vid termalne manipulacije dovodi do povećanja koncentracije hormona fT3, 19. embrionalnog dana, a nasuprot tome dovodi do smanjenja koncentracije hormona fT4 u krvi embriona u poređenju sa kontrolnom grupom. Procenat leženosti u konrolnoj grupi bio je $82,2 \%$ dok je u grupi podvrgnutoj termalnom kondicioniranju iznosio $83,3 \%$. Rezultati ukazuju da ovakav vid termalne manipulacije nije imao uticaj na ukupan embrionalni mortalitet, koji je u kontrolnoj grupi iznosio 9,5\%, a u oglednoj grupi 8,9\%. Može se zaključiti da ovakav vid termalnog kondicioniranja može ispoljiti pozitivan efekat na nivoe hormona štitaste žlezde, a da se pri tome ne poveća embrionalni mortalitet i ne naruši procenat leženosti.

Ključne reči: termalno kondicioniranje, hormoni štitaste žlezde, embrionalni mortalitet, leženost

Received / Primljen: 01.12.2017. Accepted / Prihvaćen: 04.07.2017. 